\title{
Cellobiose/mannitol sugar test - a sensitive tubeless test for coeliac disease: results on 1010 unselected patients
}

\author{
L D JUBY, J ROTHWELL, AND A $T$ R AXON \\ From the Gastroenterology Unit, The General Infirmary, Leeds
}

Summary The cellobiose/mannitol (Ce/Ma) test is a non-invasive technique for investigating intestinal permeability. In coeliac disease there is a decreased absorption of small molecules and paradoxically increased absorption of large molecules. The simultaneous administration of cellobiose and mannitol as two probe molecules allows the permeability of the small bowel mucosa to be studied, eliminating extraneous factors such as gastric emptying, and incomplete urine collection. One thousand and ten patients presenting to a gastroenterology clinic with symptoms, signs, or biochemical indices compatible with coeliac disease had a Ce/Ma test. Eight hundred and seventeen had a normal test and of these 197 had a jejunal biopsy showing 148 normal mucosa, two coeliac disease, $\mathbf{4 3}$ non-specific abnormalities, four giardiasis. One hundred and ninety three had an abnormal test; of these 132 had a jejunal biopsy showing 62 normal mucosa, 48 coeliac disease, and 22 other abnormalities. Considering those who had jejunal biopsies, the sensitivity of the test for coeliac disease is $96 \%$, specificity $70 \%$, the predictive value of the positive $36 \%$, and predictive value of the negative $99 \%$. Eleven per cent of the patients with a 'false positive' test had abnormalities in the jejunal biopsy or a diagnosis which could explain the abnormal permeability.

The Ce/Ma test is a non-invasive investigation of small bowel permeability. ${ }^{2}$ Cellobiose, a disaccharide (molecular radius $0.50 \mathrm{~nm}$ ) and mannitol, a polyhydric alcohol (molecular radius $0.40 \mathrm{~nm}$ ) are taken orally in hypertonic solution and a five hour urine collection is analysed for both probe molecules, the results being expressed as a ratio of the percentage recoveries. ${ }^{\prime}$ In coeliac disease more cellobiose and less mannitol is absorbed than in normal subjects. ${ }^{13}$ By expressing the results as a ratio there is good separation of coeliacs from normal subjects and the influence of certain non-intestinal factors acting similarly on both molecules such as renal impairment, gastric and bladder emptying and are eliminated. ${ }^{4}$

Although results of the Ce/Ma test have been reported previously they relate to small numbers of

Address for correspondence: Dr L D Juby, Gastroenterology Unit, The General Infirmary, Leeds LS1 3EX.

Accepted for publication 2 September 1988. selected groups of patients. ${ }^{135-4}$ This paper describes our experience in 1010 patients presenting to a general gastroenterology clinic with symptoms compatible with coeliac disease.

\section{Methods}

\section{$\mathrm{Ce} / \mathrm{Ma}$ TEST}

The test solution comprises $5 \mathrm{~g}$ cellobiose $(\mathrm{Ce})$ and $2 \mathrm{~g}$ mannitol (Ma), lactose $20 \mathrm{~g}$ and sucrose $20 \mathrm{~g}$ are added as osmotic fillers and the solution is made up to $100 \mathrm{ml}$ with water producing osmolality of 1500 $\mathrm{mOsmol} / \mathrm{l}$. The solution is taken orally after a six hour fast (normally at $600 \mathrm{am}$ ). A baseline urine specimen is obtained and urine collected for five hours into $1 \%$ thiomersal as a preservative. In nearly all cases this procedure was done as an outpatient at home, only occasionally as an inpatient.

Cellobiose absorption was measured by quantitative paper chromatography" and mannitol by spectrophotometry as previously described. ${ }^{1 "}$ The 
results are expressed as a ratio of percentage $\mathrm{Ce}$ recovery to percentage Ma recovery. (Normal range 0.004-0.028 calculated in 50 patients with normal jejunal biopsies.)

JEJUNA L BIOPSY

Jejunal biopsies were performed with a Watson biopsy capsule under $x$-ray control (263 patients) or through oral gastroduodenoscopy with large biopsy forceps (66 patients). Coeliac disease was defined as the finding of partial villous atrophy on jejunal biopsy with clinical and in some cases biopsy response to a gluten free diet.

\section{PATIENTS}

Records of 1010 new patients who had undertaken the Ce/Ma test between 1978 and 1985 were reviewed (age 18-85 years). These had presented to a general gastroenterology clinic with symptoms or biochemical findings compatible with coeliac disease.

\section{Results}

Eight hundred and seventeen patients had a normal $\mathrm{Ce} / \mathrm{Ma}$ test and of these 197 had a jejunal biopsy $(24 \cdot 11 \%)$. One hundred and ninety three patients had an abnormal test of whom 132 had a jejunal biopsy $(68 \cdot 39 \%)$. The overall biopsy rate was

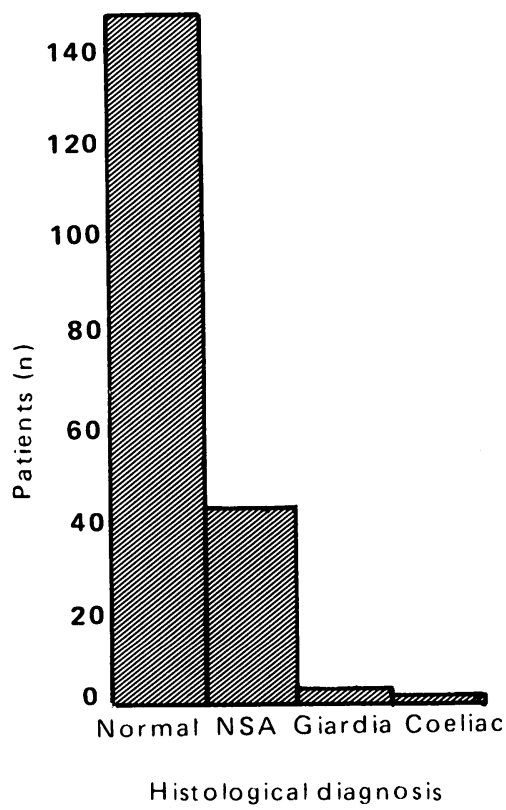

Fig. 1 Jejunal biopsy result in normal Ce/Ma test group. $N S A=$ non-specific abnormality, presence of chronic inflammatory cells \pm minor changes in architecture.

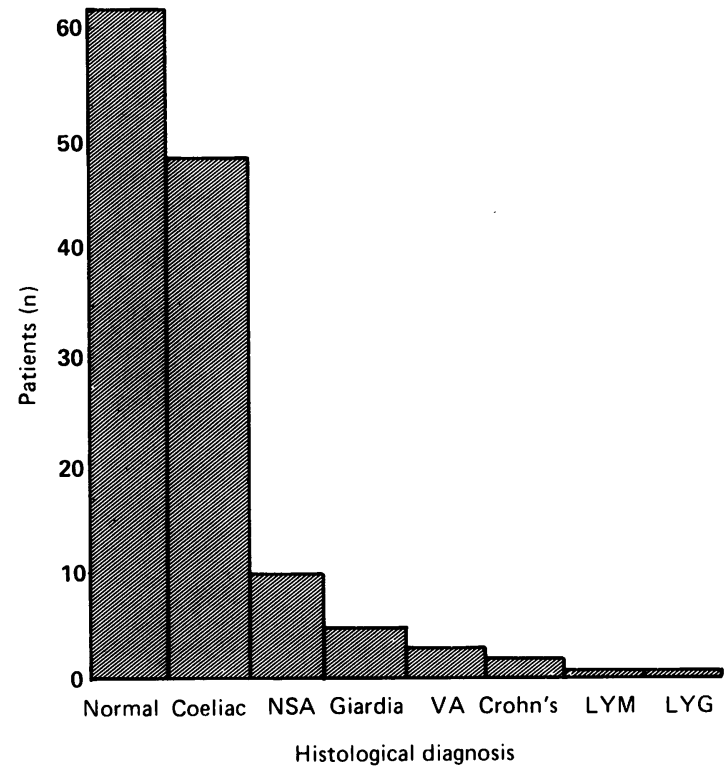

Fig. 2 Jejunal biopsy result in abnormal CelMa test group. $N S A=$ non-specific abnormality, presence of chronic inflammatory cells \pm minor changes in architecture. $V A=$ villous atrophy not coeliac disease. $L Y M=$ lymphoma. $L Y G=$ lymphangiectasia.

$32 \cdot 57 \%$. In the normal test group there were 148 normal biopsies $(75 \cdot 12 \%)$, two coeliac disease $(1.01 \%)$, and $47(23.85 \%)$ with abnormalities other than coeliac disease (Fig. 1). In the abnormal test group $62(46.96 \%)$ had a normal jejunal biopsy, 48 $(36 \cdot 36 \%)$ had coeliac disease, and $22(16 \cdot 66 \%)$ abnormalities other than coeliac disease (Fig. 2). Those with non-specific abnormalities on duodenal biopsy underwent a jejunal biopsy using the Watson capsule to exclude coeliac disease. In the group that had a gastroscopic biopsy $50 \%$ of biopsies were abnormal and in the jejunal biopsy group 13\% abnormal. This reflects the proportion of abnormal sugar tests in each group (jejunal biopsy $13 \%, \mathrm{~GB}$ $47 \%$ ) rather than the type of biopsy performed.

The Table shows the diagnoses made in the patients with an abnormal Ce/Ma test.

\section{SENSITIVITY AND SPECIFICITY OFTHE Ce/Ma TEST}

The sensitivity of a test measures the ability to identify those patients who have the disease, and the specificity, those that do not have the disease. ${ }^{12}$ For those patients who had a jejunal biopsy the sensitivity of the Ce/Ma test for coeliac disease is $96 \%$ and specificity $70 \%$ with the predictive value of the positive $36 \%$ and negative $99 \%$.

There is a bias in these results because a greater 
Table Diagnosis in the abnormal CelMa test group

\begin{tabular}{|c|c|c|c|c|c|}
\hline Diagnosis & $n$ & $N$ & $N S A$ & $N P$ & Other \\
\hline Coeliac disease & 48 & - & - & - & $\begin{array}{r}48 \text { Villous } \\
\text { atrophy }\end{array}$ \\
\hline Irritable bowel syndrome & 21 & 16 & 1 & 4 & \\
\hline $\begin{array}{l}\text { No diagnosis but became } \\
\text { asymptomatic }\end{array}$ & 20 & 13 & 1 & 6 & \\
\hline Radiation enteritis & 2 & 2 & - & - & \\
\hline Crohn's disease & 9 & 2 & - & 5 & $\begin{array}{l}2 \text { Changes } \\
\text { consistent } \\
\text { with Crohn's } \\
\text { of small bowel }\end{array}$ \\
\hline Metastatic bone disease & 1 & - & - & 1 & \\
\hline Myxoedema & 1 & - & - & 1 & \\
\hline $\begin{array}{l}\text { Iron deficiency anaemia? } \\
\text { cause }\end{array}$ & 5 & 5 & - & - & \\
\hline Primary osteoporosis & 3 & - & 1 & 2 & \\
\hline $\begin{array}{l}\text { Died before investigated } \\
\text { further }\end{array}$ & 2 & - & - & 2 & \\
\hline ? Sprue & 1 & - & - & - & $1 \mathrm{VA}$ \\
\hline Giardiasis & 5 & - & - & - & 5 Giardiasis \\
\hline $\begin{array}{l}\text { Non-steroidal anti- } \\
\text { inflammatory drugs }\end{array}$ & 3 & 3 & - & - & \\
\hline Alcoholic & 3 & 2 & - & 1 & \\
\hline Gall stones & 1 & - & - & 1 & \\
\hline $\begin{array}{l}\text { Crohn's disease causing oral } \\
\text { aphthae }\end{array}$ & 1 & 1 & - & - & \\
\hline $\begin{array}{l}\text { Malabsorption in chronic } \\
\text { renal failure }\end{array}$ & 1 & - & - & - & $1 \mathrm{VA}$ \\
\hline Thyrotoxic & 1 & - & - & - & $1 \mathrm{VA}$ \\
\hline Duodenitis & 3 & - & 3 & - & \\
\hline Bacterial overgrowth & 3 & 2 & 1 & - & \\
\hline Small bowel lymphoma & 1 & - & - & - & Lymphoma \\
\hline Eczema & 1 & - & - & 1 & \\
\hline Gastric ulcer & 1 & 1 & - & - & \\
\hline Dietary anaemia & 3 & 2 & 1 & - & \\
\hline Dermatitis herpetiformis & 1 & - & - & 1 & \\
\hline Anorexia nervosa & 2 & 2 & - & - & \\
\hline Carcinoma pancreas & 1 & - & 1 & - & \\
\hline $\begin{array}{l}\text { Anaemia due to uterine } \\
\text { fibroids }\end{array}$ & 1 & 1 & - & - & \\
\hline Tuberculosis (respiratory) & 1 & 1 & - & - & \\
\hline Abdominal migraine & 1 & 1 & - & - & \\
\hline Lymphangiectasia & 2 & - & 1 & - & $\begin{array}{l}1 \text { Lymphan- } \\
\text { giectasia }\end{array}$ \\
\hline Allergic to eggs & 1 & 1 & - & - & \\
\hline Laxative abuse & 1 & 1 & - & - & \\
\hline $\begin{array}{l}\text { Iron deficiency secondary to } \\
\text { gastric surgery }\end{array}$ & 1 & - & - & 1 & \\
\hline Pancreatitis & 1 & - & - & 1 & \\
\hline Non-specific colitis & 1 & 1 & - & - & \\
\hline Diverticular disease & 1 & 1 & - & - & \\
\hline Sarcoidosis & 1 & - & - & 1 & \\
\hline Discoid lupus & 1 & - & - & 1 & \\
\hline $\begin{array}{l}\text { Idiopathic oral aphthous } \\
\text { ulceration }\end{array}$ & 1 & 1 & - & - & \\
\hline Failed to attend for follow up & 35 & 3 & - & 32 & \\
\hline Total & 193 & 62 & 10 & 61 & 60 \\
\hline
\end{tabular}

$\mathrm{n}=$ number tests; $\mathrm{N}=$ normal $\mathrm{JB} ; \mathrm{NSA}=$ non-specific abnormalities; $\mathrm{NP}=$ not performed; $\mathrm{VA}=$ villous atrophy not coeliac disease.

number of biopsies were done on those patients who had an abnormal test. If the patients who were not biopsied were assumed to have the same distribution as those who were biopsied, the sensitivity would be
$91 \%$, specificity $88 \%$, predictive value of the positive $43 \%$ and negative $99 \%$. Considering detection of any small bowel disease diagnosed by jejunal biopsy or other means the sensitivity is $91 \%$, specificity $73 \%$, predictive value positive $45 \%$ and negative $97 \%$.

\section{Discussion}

In coeliac disease there is a reduced absorption of small molecules - for example, low molecular weight PEG,,$^{1314}$ monosaccharides, ${ }^{515}$ mannitol, ${ }^{1-36}$ and increased absorption of relatively larger molecules for example, CrEDTA,${ }^{16}$ lactulose and cellobiose ${ }^{1718}$ which is enhanced by hypertonicity of the solute. ${ }^{17-19}$ The absorption of small molecules of less than $0.5 \mathrm{nM}$ diameter is $10-200$-fold that of molecules greater than $0.50 \mathrm{nM}$ suggesting, in the absence of active transport, that whilst small molecules are absorbed through classical aqueous pore ${ }^{20}$ large molecules are excluded by their size. The paradoxical changes in absorption of different sized molecules which occurs in coeliac disease and in experimental animals ${ }^{21}$ also suggests different routes for absorption. The absorption route of large molecules may be through intercellular tight junctions ${ }^{22}$ or cell extrusion zones at the villous tips, ${ }^{18}$ thus the increased disaccharide absorption in coeliac disease may reflect epithelial injury, cell shedding or changes in the tight junction..$^{23}$ The decreased absorption of small molecules may result from a reduction in the number of aqueous pores secondary to a reduced surface area..$^{24}$

The Ce/Ma sugar test is highly sensitive for coeliac disease (sensitivity $96 \%$ ). Only two coeliac patients were identified in this study with a normal sugar test. The first, a woman of 40 complained of indigestion. A barium meal showed gastric erosions and a routine full blood count revealed a high mean cell volume caused by folate deficiency. She therefore had a Ce/ Ma test and jejunal biopsy which showed changes typical of coeliac disease, she had no symptoms of coeliac disease at presentation. The second patient, a woman of 50 years, presented with diarrhoea and weight loss. An investigation plan for diarrhoea included a Ce/Ma test, jejunal biopsy, and thyroid function tests, the latter showing her to be thyrotoxic. She was treated for the thyrotoxicosis and the diarrhoea ceased. The jejunal biopsy was then reported as coeliac disease, her presenting symptoms were caused by thyrotoxicosis, coeliac disease being an incidental finding.

Earlier work from our laboratory ${ }^{2}$ compared the $\mathrm{Ce} / \mathrm{Ma}$ test with the xylose test, serum and red cell folate, and reticulin antibodies in a group of patients comprising 24 coeliacs, 54 with normal jejunal biopsy, and 50 disease controls. The results showed sensitivities and specificities of 96 and $99 \%$ for the Ce/Ma test, 67 and $67 \%$ for the xylose test, 62 and 
$78 \%$ for serum folate, 46 and $95 \%$ for red cell folate, and 44 and $97 \%$ for reticulin antibodies. Negative predictive values were $99 \%, 76 \%, 82 \%, 82 \%$, and $82 \%$ respectively. The Ce/Ma test, therefore, appears to be an excellent screen for coeliac disease when compared with other investigations. In this study $25 \%$ of the patients with abnormal tests had coeliac disease giving a specificity of $70 \%$. The Table shows the Ce/Ma test was abnormal in other small bowel diseases where a change in permeability is known to occur - for example, Crohn's disease, ${ }^{7825}$ alcoholics, ${ }^{26}$ patients taking non-steroidal antiinflammatory agents, ${ }^{97}$ eczema, ${ }^{2829}$ food allergy, ${ }^{30}$ and dermatitis herpetiformis ${ }^{31}(9 \cdot 3 \%)$. A change in permeability might be expected in certain other conditions - for example, radiation enteritis, giardiasis, sprue, small bowel lymphoma, lymphangiectasia and duodenitis $(7 \cdot 30 \%)$ when there is a change in the morphology of the jejunum which might disrupt normal absorptive pathways. Permeability in other disease such as thyroid disease, primary osteoporosis, metastatic disease, cholelithiasis, renal failure, peptic ulcer disease, anorexia nervosa, pancreatic inflammation and carcinoma, gastric surgery, sarcoidosis and discoid lupus has not been fully studied and at present these are either isolated cases or falsely positive tests.

In the five cases of iron deficiency anaemia the gastrointestinal tract was fully investigated and no cause for blood loss found, the iron deficiency may have been caused by iron malabsorption reflected by the abnormal permeability, or it is possible that iron deficiency affects intestinal permeability.

There was only one proven case of food allergy in this study and it would be interesting to study permeability changes in a larger group of these.

Fifty nine per cent of tests appear to be false positives, however, it may be that there is a change in permeability but not in jejunal morphology which might account for some of the abnormal Ce/Ma tests with normal jejunal biopsies. Recent studies have shown that although the jejunal biopsy may be normal on routine microscopy there is often a change in morphometry when analysed using a computerised measuring facility. ${ }^{32}$

In conclusion the $\mathrm{Ce} / \mathrm{Ma}$ test is a sensitive and specific test for coeliac disease. The low predictive value of a positive test reflects the low prevalence of the disease in the population studied whilst the high predictive value of a negative test means it can be relied on to miss only a few patients with coeliac disease.

\section{References}

1 Cobden I, Dickinson RJ, Rothwell J, Axon ATR.
Intestinal permeability assessed by excretion ratios of two molecules: results in coeliac disease. $\mathrm{Br} \mathrm{Med} \mathrm{J} \mathrm{1978;}$ ii: $1060-1$.

2 Cobden I, Rothwell J, Axon ATR. Intestinal permeability and screening tests for coeliac disease. Gut 1980; 21: 512-8.

3 Strobel S, Brydon WG, Ferguson A. Cellobiose/ Mannitol sugar permeability test complements biopsy histopathology in clinical investigation of the jejunum. Gut 1984; 25: 1241-6.

4 Cobden I, Hamilton I, Rothwell J, Axon ATR. Cellobiose/Mannitol test: physiological properties of probe molecules and influence of extraneous factors. Clin Chim Acta 1985; 148: 53-62.

5 Menzies IS, Laker MF, Pounder R, et al. Abnormal intestinal permeability to sugars in villous atrophy. Lancet 1979; ii: 1107-9.

6 Ukabam SO, Clamp J, Cooper BT. Is small intestinal permeability increased or decreased in coeliac disease. Clin Sci 1981; 61: 39.

7 Pearson ADJ, Eastham EJ, Laker MF, Craft AW, Nelson R. Intestinal permeability in children with Crohn's disease and coeliac disease. Br Med J 1982; 285: 20-1.

8 Gomes M de FA, Dunne J, Logan LH, Pounder RE. Non-invasive assessment of small intestinal damage in Crohn's disease and ulcerative colitis [Abstract]. Gut 1983; 24: A486.

9 Juby LD, Axon ATR, Wright V, Winstanley P, Rothwell J. Intestinal permeability and inflammation in rheumatoid arthritis. Br J Rheumatol 1986; 25: 226-7.

10 Menzies IS. Quantitative estimation of sugars in blood and urine by paper chromatography using direct densitometry. J Chromatogr 1973; 81: 109-27.

11 Cobden I. Newcastle upon Tyne: M.D. thesis; 1980.

12 Pitkin FB. Statistics made easy. Edinburgh: Churchill Livingstone, 1986.

13 Chadwick VS, Phillips SF, Hofmann AF. Measurements of intestinal permeability using low molecular weight polyethylene glycols (PEG 400). Gastroenterology 1977; 73: 247-51.

14 Ukabam SO, Cooper BT. Small intestinal permeability to mannitol, lactulose and PEG $\mathbf{4 0 0}$ in coeliac disease. Dig Dis Sci 1984; 29: 809-16.

15 Gomes ME, Lokschin F, Logan L, Pounder RE. Non invasive assessment of small intestinal damage. Scand J Gastroenterol 1982; 17 [Suppl 78]: 285.

16 Bjarnason I, Peters TJ, Veall N. A persistent defect in intestinal permeability in coeliac disease demonstrated by a ${ }^{51} \mathrm{Cr}$ labelled EDTA absorption test. Lancet 1983; i: 323-5.

17 Menzies IS. Absorption of intact oligosaccharides in health and disease. Biochem Soc Trans 1974; 2: 1042-7.

18 Wheeler PG, Menzies IS, Creamer B. Effect of hyperosmolar stimuli and coeliac disease on the permeability of the human gastrointestinal tract. Clin Sci Mol Med 1978; 54: 495-501.

19 Laker MF, Menzies IS. Increase in human intestinal permeability following ingestion of hypertonic solutions. J Physiol 1977; 265: 881-94.

20 Soloman AK, Chasan B, Dix JA, Lukacovic MF, Toon MR, Verkman AS. The aqueous pore in the red cell 
membranc. Ann NY Acad Sci 1984; 414: 97-124.

21 Cobden I, Rothwell J, Axon ATR. Intestinal permeability in rats infected by Nippostrongylus brasiliensis. Gut 1979; 20: 716-21.

22 Fromter E, Diamond J. Route of passive ion permeation in epithelia. Nature New Biol 1972; 235: 9-13.

23 Axon ATR, Creamer B. The exsorption characteristics of various sugars. Gut 1975; 16: 99-104.

24 Fordtran JS, Rector FC, Locklear TW, Ewton MF. Water and solute movement in the small intestine of patients with sprue. J Clin Invest 1967; 46: 287-98.

25 Ukabam SO, Clamp JR, Cooper BT. Abnormal intestinal permeability to sugars in patients with Crohn's disease of the terminal ileum and colon. Digestion 1982; 27: 70-4.

26 Robinson GM, Orrego H, Israel Y, Devenyi P, Kapur BM. Low molecular weight PEG as a probe of gastrointestinal permeability alter alcohol ingestion. Dig Dis Sci 1981; 26: 971-7.
27 Bjarnason I, Williams $\mathrm{P}$, So $\mathrm{A}$, et al. Intestinal permeability and inflammation in rheumatoid arthritis: effects of non-steroidal anti-inflammatory agents. Lancet 1984; ii: 1171-3.

28 Jackson PJ, Lessof MH, Baker RWR, Ferrett J, Macdonald DM. Intestinal permeability in patients with eczema and food allergy. Lancet 1981 ; i: $1285-6$.

29 Ukabam SO, Mann RJ, Cooper BT. Small intestinal permeability to sugars in patients with atopic eczema. Br J Dermatol 1984; 110: 649-52.

30) DuMont GCL, Beach RC, Menzies IS. Gastrointestinal permeability in food allergic eczematous children. Clin Allergy 1984; 14: 55-9.

31 Bjarnason I, Marsh MN, Price A, Levi AJ, Peters TJ. Intestinal permeability in patients with coeliac disease and dermatitis herpetiformis. Gut 1985; 26: 1214-9.

32 Juby LD, Dixon MF, Axon ATR. Abnormal intestinal permeability and jejunal morphometry. J Clin Pathol 1987; 40: 714-8. 